\title{
Measurement of Serum IgG4 Levels by a Competitive Immunoenzymatic Assay with Monoclonal Antibodies *
}

\author{
Pierre Aucouturier ${ }^{1}$, Françoise Danon ${ }^{2}$, Maryvonne Daveau ${ }^{3}$, \\ Bernard Guillou ${ }^{4}$, Alfred Sabbah ${ }^{5}$, Jacques Besson ${ }^{6}$ \\ and Jean Louis Preud'homme ${ }^{1 . * *}$ \\ ' Laboratoire d'Immunologie et Immunopathologie, C.H.R.U. La Milétrie, Poitiers, ' Laboratoire \\ d'Immunochimie et Immunopathologie (INSERM U 108), Hôpital Saint-Louis, Paris, ${ }^{3}$ Unité de Recherches \\ sur la Génétique des Protéines Humaines (INSERM U 78), Bois-Guillaume, ${ }^{4}$ Laboratoire de Thermique de \\ I'ENSMA (LA 19I du CNRS), Poitiers, ' Laboratoire d'Immunoallergologie, C.H.U.R. d'Angers, and \\ ${ }^{5}$ Département de Statistique, Faculté de Médecine, Poitiers, France
}

(Received 9 April 1984, accepted 24 July 1984)

A competitive indirect ELISA is described for the measurement of IgG4 levels. It uses a monoclonal anti-subclass antibody and purified monoclonal IgG4 as standards. This method is sensitive and reproducible and more accurate than hemagglutination inhibition and radial immunodiffusion. Serum IgG4 levels in 173 normal adults were $<0.01-2.1 \mathrm{mg} / \mathrm{ml}($ mean $0.30 \mathrm{mg} / \mathrm{ml})$ in women and $<0.01-1.87$ $\mathrm{mg} / \mathrm{ml}$ (mean $0.465 \mathrm{mg} / \mathrm{ml})$ in men.

Key words: immunoglobulin subclasses - competitive ELISA - monoclonal antibodies

\section{Introduction}

The clinical importance of a precise measurement of serum IgG subclass levels has long been recognized (Terry, 1968; Schur et al., 1970; Yount et al., 1970; Natvig and Kunkel, 1973) but technical problems, mostly linked to the well known difficulty in obtaining strictly monospecific polyclonal anti-subclass antisera, has restricted the number of studies of IgG subclasses in normal and patients' sera to a few. The measurement of IgG4 levels seems to be of special clinical interest. Indeed, alterations in serum IgG4 levels have been observed in various primary immunodeficiency states, including ataxia-telangiectasia and selective IgA deficiency with

\footnotetext{
* This work was supported by a grant of Ministère de la Recherche et de l'Industrie (No. 82.P.0407 of D.D.S.T.I.) and by the Fondation pour la Recherche Médicale.

** Correspondence to: J.L. Preud'homme, Laboratoire d'Immunologie et Immunopathologie, C.H.U.R. La Milétrie, BP 577, 86021 Poitiers, France.
} 
frequent association with $\mathrm{IgG} 2$ defect and correlation with frequency of infections (Terry, 1968; Rivat et al., 1969; Schur et al., 1970; Yount et al., 1970; Natvig et al., 1971; Oxelius, 1974, 1979b; Yount, 1975; Morell et al., 1975; Rivat-Peran et al., 1981; Oxelius et al., 1981, 1982; Lefranc et al., 1983; Ugazio et al., 1983), in atopic allergy (Parish, 1981; Merret et al., 1983), in malignant melanoma (Daveau et al., 1977) and in certain respiratory diseases (Van Nieuwkoop et al., 1982).

Normal figures for serum IgG4 levels were previously reported in studies based upon various methods: radioimmunoassay (Morell et al., 1972: Merret et al., 1983), single radial immunodiffusion (Yount et al., 1970, 1975; Shakib et al., 1975; Van der Giessen et al., 1975; Kaschka et al., 1982; Van Nieuwkoop et al., 1982; Sabbah et al., 1983), electroimmunodiffusion (Oxelius, 1978, 1979a, b), nephelometry (Beck and Kaiser, 1981) and immunoenzymatic assay (ELISA) (Linde et al., 1983). The last study used a sandwich-ELISA method with a monoclonal antibody (Mab) but dealt with a very small number of samples. Other published work has been performed with polyclonal antibodies and agreement between results is not perfect (see below). One method (nephelometry) seemed appealing because of its apparent easiness but careful experiments performed under the same technical conditions and with the same polyclonal reagents as described by Beck and Kaiser (1981) were completely unsuccessful (Hurez, 1983, personal communication). These considerations and the recent availability of Mabs specific for the 4 human IgG subclasses led us to develop quantitative ELISA tests based upon such antibodies. In view of the results of preliminary experiments performed under various conditions (by coating either antigens or antibodies and developing with either enzyme-coupled antibodies or standard antigens) and also for theoretical reasons (Pratt and Woldring, 1976), we have employed indirect competitive immunoenzymatic assay. This proved accurate and reproducible. We report here IgG4 level determinations in 173 normal adult sera. Figures obtained by ELISA were compared with those obtained by radial immunodiffusion or by a semi-quantitative hemagglutination inhibition assay in sera from patients with atopic allergy or melanoma.

\section{Material and Methods}

The competitive ELISA herein described employed monoclonal antibodies that were allowed to react with plastic coated human $\operatorname{IgG}$ in the presence of either the serum to be measured or known amounts of standard IgG4 myeloma proteins as inhibitors. Binding of residual free Mabs was measured with rabbit anti-mouse IgG (MIg) peroxidase conjugate.

\section{Monoclonal antibodies}

Nine Mabs against the $4 \mathrm{IgG}$ subclasses were used to determine the subclass of myeloma proteins and in the quantitative assay. These reagents were either generous gifts of Drs. I.C.M. MacLennan (Lowe et al., 1982; Walker et al., 1983), J.D. Capra, M.D. Cooper and C.B. Reimer or were obtained commercially from Seward, Bedford, U.K. Specificity was controlled by ELISA using purified myeloma proteins 
of known subclasses, as previously determined by double immunodiffusion with polyclonal antisera kindly provided by Dr. F. Skvaril. The Mab used in the IgG4 assay was clone RJ4, given by Dr. MacLennan or purchased from Seward.

\section{Standard IgG4 myeloma proteins}

Sera from patients with IgG myeloma were selected for their very low content of residual polyclonal immunoglobulins $(\mathrm{Ig})$. The myeloma proteins were typed for $\mathrm{IgG}$ subclasses by competitive ELISA assay: microtitration plates (ref. M29A, Dynatech, Billinghurst, U.K.) were coated with $150 \mu \mathrm{l}$ /well of either DEAE-cellulose-purified normal polyclonal IgG at $10 \mu \mathrm{g} / \mathrm{ml}$ (for the determination of $\operatorname{IgG} 1,2$ and 3) or a known purified monoclonal IgG4 at $5 \mu \mathrm{g} / \mathrm{ml}$ (for IgG4 typing); $75 \mu 1$ of myeloma serum diluted 1 in 100 and $75 \mu \mathrm{l}$ of anti-subclass Mab at the proper dilution were added, then the peroxidase anti-MIg conjugate as described below. Typing by this inhibition procedure was in perfect agreement with that obtained by Ouchterlony analysis with Dr. Skvaril's antisera.

Amongst 47 monoclonal IgG typed, 5 were found to belong to the IgG4 subclass (versus $34 \mathrm{IgG} 1,4 \mathrm{IgG} 2$ and $4 \mathrm{IgG} 3$ ). They were isolated by chromatography on DEAE-Trisacryl (IBF, Villeneuve la Garenne, France) in phosphate buffer, 0.0175 $\mathrm{M}, \mathrm{pH} 7.5$ and concentrated by vacuum dialysis against phosphate buffer, $0.01 \mathrm{M}$, pH 7.4, $0.15 \mathrm{M}$ in $\mathrm{NaCl}$ (phosphate buffered saline, PBS). Comparable inhibition of the binding of RJ4 to plastic coated with IgG4 was found with these different monoclonal IgG4. Purity was controlled by immunoelectrophoretic and Ouchterlony analyses with anti-normal human serum, polyvalent anti-Ig and monospecific anti-Ig chain sera (Dako, Copenhagen, Denmark) and by ELISA with anti-subclass Mabs as described below. The two purest monoclonal IgG4 (containing no other protein detectable by gel double diffusion and less than $1 \%$ IgG1 by competitive ELISA) were pooled and kept at $-20^{\circ} \mathrm{C}$ at a concentration of $1 \mathrm{mg} / \mathrm{ml}$ in $0.1 \mathrm{ml}$ aliquots.

\section{Anti-mouse IgG peroxidase-conjugate}

Rabbits were hyperimmunized for more than 6 months with mouse IgG (Sigma, St. Louis, MO). Pooled sera were adsorbed on human polyclonal IgG coupled to Sepharose 4B (Pharmacia, Uppsala, Sweden) with cyanogen bromide (March et al., 1974) until antibodies cross-reacting with human IgG were no longer detectable by gel double diffusion ( 6 adsorptions). The $\mathrm{IgG}$ fraction of this adsorbed antiserum was isolated by a combination of ammonium sulfate precipitation and DEAE-Trisacryl chromatography, concentrated and conjugated to horseradish peroxidase type I (Boehringher, Mannheim, G.F.R.) by the 2-step glutaraldehyde coupling procedure (Avrameas and Ternynck, 1971). The specificity and titer of the conjugate were studied by direct ELISA with microplates either uncoated or coated with 1-10 $\mu \mathrm{g} / \mathrm{ml}$ mouse or human IgG. At the optimal dilution (about $2.5 \mu \mathrm{g}$ of $\mathrm{IgG} / \mathrm{ml}$ ) and at higher concentrations, the cross-reaction with human $\mathrm{IgG}$ was negligible (not different from the very low background due to non-specific binding on uncoated polystyrene). The anti-mouse IgG-horseradish peroxidase conjugate (anti-MIg-HRP) was kept frozen in small aliquots in $50 \% \mathrm{v} / \mathrm{v}$ glycerol. 


\section{Coating of the plates}

Comparison of several models of microplates from several manufacturers led us to choose ordinary polystyrene microtitration plates with 96 flat-bottomed wells (Dynatech). The more expensive plates specially treated for ELISA yielded very high backgrounds due to non-specific binding in this and other ELISA assays and irrespective of the saturation procedure used. Samples of $150 \mu 1$ per well of a 5 $\mu \mathrm{g} / \mathrm{ml}$ solution of purified monoclonal IgG4 in carbonate buffer, $0.1 \mathrm{M}, \mathrm{pH} 9.6$ were incubated overnight at $4{ }^{\circ} \mathrm{C}$ in a moist chamber. After two washes with PBS. the plates were filled with PBS containing $0.2 \%$ bovine serum albumin (BSA, IBF) and incubated at $37^{\circ} \mathrm{C}$ for $45 \mathrm{~min}$ (for saturation), then washed again with PBS. The coated plates were either used immediately or dessicated under vacuum and stored at $-80^{\circ} \mathrm{C}$ without appreciable loss of antigenic activity.

\section{Quantitative ELISA test}

Each plate included the standard IgG4 myeloma protein preparation at 6 concentrations (to establish a calibration curve in every experiment), the same control serum and the sera to be tested at the proper dilution (see below). Standards and sera were diluted in PBS-2\% BSA and distributed in $75 \mu \mathrm{l}$ quadruplicates on coated plates. The same volume of the anti-IgG4 Mab (RJ4 ascites diluted 1:3000 in the same buffer, as determined by preliminary experiments with various concentrations of the Mab) was added and mixed immediately with a 12-channel automatic pipet. After incubation for $2.5 \mathrm{~h}$ at $37^{\circ} \mathrm{C}$ in a moist chamber, the plates were washed 6 times with PBS containing 0.05\% Tween 20 (Merck, Darmstadt, G.F.R.) with a manual washer (Immunowash 8, Nunc, Roskilde, Denmark). Each well was then filled with $200 \mu \mathrm{l}$ of anti-MIg-HRP at about $2.5 \mu \mathrm{g} / \mathrm{ml}$ in PBS-Tween for a further incubation of $1 \mathrm{~h}$ at $37^{\circ} \mathrm{C}$ followed by 6 washes with PBS-Tween and 2 washes with distilled water. Bound conjugate was revealed by adding $200 \mu \mathrm{l} /$ well of a solution of $0.4 \mathrm{mg} / \mathrm{ml} \mathrm{o-phenylenediamine} \mathrm{(Sigma)} \mathrm{and} 0.4 \mu \mathrm{l} / \mathrm{ml} 30 \% \mathrm{H}_{2} \mathrm{O}_{2}$ in phosphatecitrate buffer, $0.05 \mathrm{M}, \mathrm{pH} 5$ as a substrate. The enzyme reaction was stopped by adding $50 \mu \mathrm{l} /$ well of $12.5 \% \mathrm{H}_{2} \mathrm{SO}_{4}$. Optical densities were recorded on a microplate reader (Titertek Multiskan, Flow Labs., McLean, VA).

\section{Sera studied and comparison with other technics}

Serum was obtained from 173 blood donors ( 75 women and 98 men aged 22-59 years). Results obtained in the 2 sexes were compared by the Student's $t$-test. The same test corrected for paired series was applied to analysis of the results for 2 different dilutions of the individual sera.

Sera from patients with either malignant melanoma or allergy were used to compare by linear regression analysis the results obtained by ELISA with those of two other techniques, radial immunodiffusion (RID) and hemagglutination inhibition technique (HIT). RID was performed with a polyclonal anti-IgG4 antiserum (Kallestadt, Chaska, MN) by reference to the dilution curve of a standard serum (Kallestadt) (Sabbah et al., 1983). For HIT, a monoclonal IgG4 protein was coupled to human red blood cells by the chromium chloride method. Hemagglutination inhibition experiments were performed with the sera to be tested by comparison with 
a normal serum pool (with an inhibition titer of $1 / 256$ ), with a rabbit anti-IgG4 antiserum (Rivat et al., 1974).

\section{Results}

Fig. 1 shows an example of the calibration curve included in every ELISA plate. From such curves, a mathematical model may be calculated, with the following equation for the relationship between optical densities (O.D.) and IgG4 concentrations (C):

O.D. $=$ O.D. $(1+\mathrm{AC})^{-\mathrm{N}}$

where O.D. ${ }_{0}$ is the O.D. corresponding to $\mathrm{C}=0$ and $\mathrm{A}$ and $\mathrm{N}$ are parameters specific to each experiment and dependent upon experimental fluctuations. In the experiment shown in Fig. 1, these values were 0.369 and 0.687 for $\mathrm{A}$ and $\mathrm{N}$ respectively (as determined with a microcomputer (ORIC, Cambridge, U.K.)) and the correlation between experimental data and figures expected from the equation

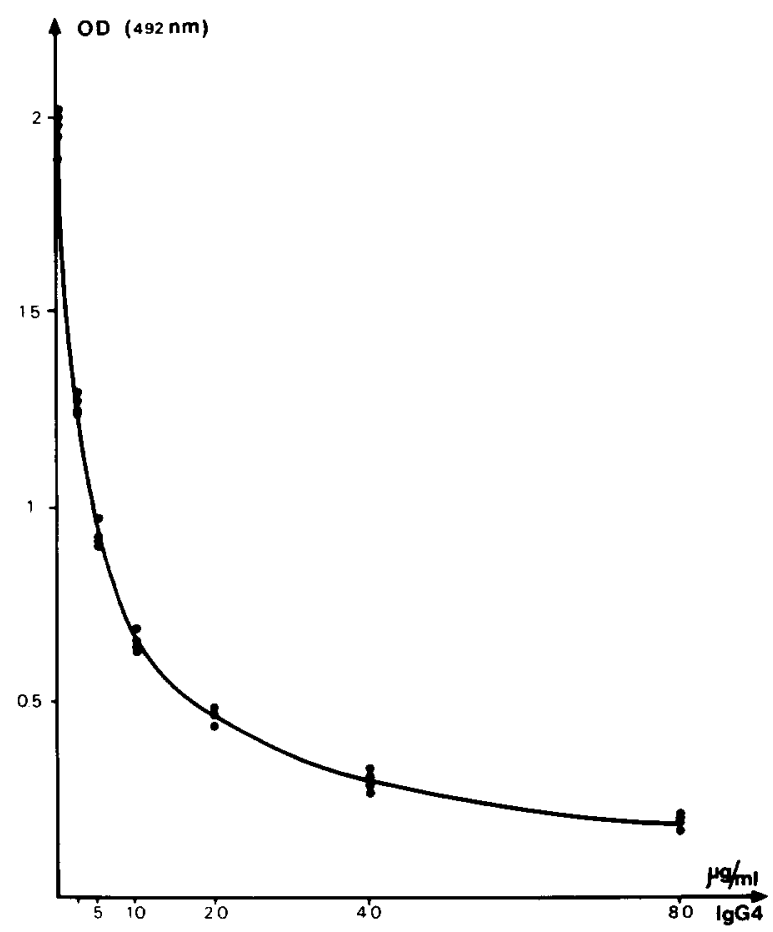

Fig. 1. Typical example of the calibration curve established for each ELISA plate with known amounts of a mixture of two purified monoclonal IgG4. 
TABLE I

CORRELATION BETWEEN EXPERIMENTAL DATA AND THEORETICAL VALUES CALCULATED FROM THE EQUATION OF THE STANDARD CURVE SHOWN IN FIG. 1

\begin{tabular}{lrrrrrrr}
\hline $\begin{array}{l}\text { IgG4 concentration } \\
(\mu \mathrm{g} / \mathrm{ml})\end{array}$ & 0 & 2.5 & 5 & 10 & 20 & 40 & 80 \\
\hline Calculated O.D. & O.D.0 $=1.950$ & 1.244 & 0.951 & 0.674 & 0.453 & 0.293 & 0.186 \\
Observed O.D. & 1.950 & 1.260 & 0.928 & 0.660 & 0.467 & 0.305 & 0.188 \\
\hline
\end{tabular}

was acceptable (Table I) in spite of the oversimplification of the mathematical formula. The reproducibility of such calibration curves being established, the same normal serum pool was repeatedly examined at various dilutions from $1 / 8$ to $1 / 32$ to determine the range of dilutions usable in the assay. The relationship between IgG4 concentrations found in the diluted samples and dilutions was roughly linear between 1/12 and 1/32 (Fig. 2). However, in most normal sera, dilution higher than $1 / 25$ led to inaccurate measurements. Thirty-seven individual normal sera were tested at 2 dilutions: $1 / 15$ and 1/20. No significant difference was found between the results $(t=1.65)$. We, therefore, decided to use a $1 / 20$ dilution for each sample, since this dilution allowed measurement of serum IgG4 initial concentrations as low as $0.01 \mathrm{mg} / \mathrm{ml}$ with acceptable precision, and the majority of the sera studied contained amounts of IgG4 that were well within the linear part of the dilution curve. Occasional sera containing more than $1 \mathrm{mg} / \mathrm{ml}$ were further diluted $1 / 30$ for more precise determination.

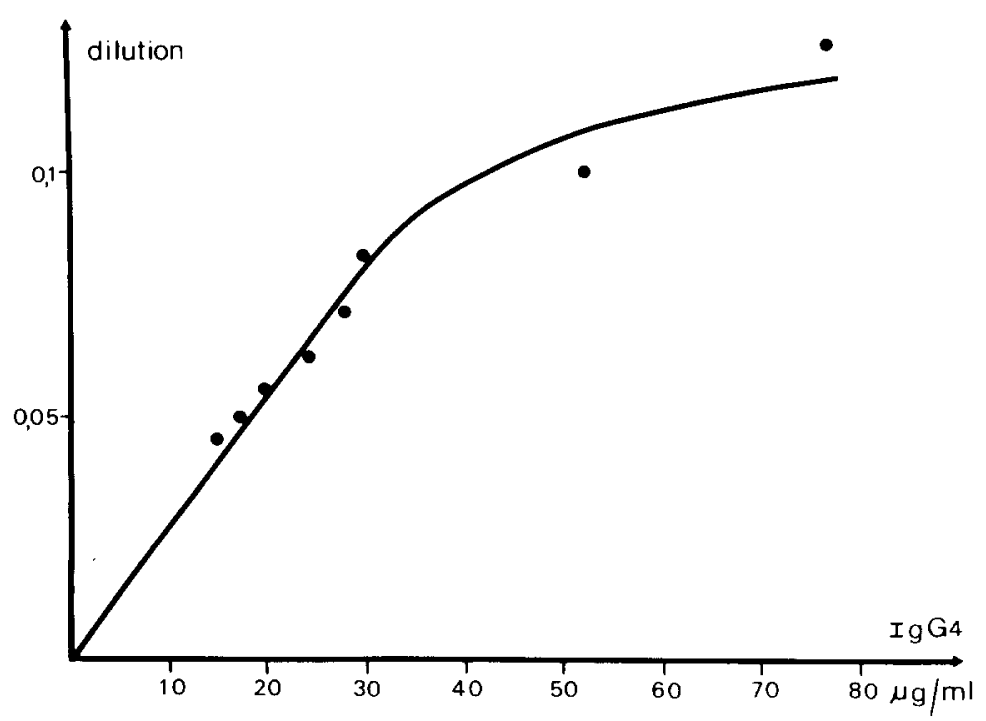

Fig. 2. Actual concentrations found as a function of the dilutions of a serum containing initially 0.36 $\mathrm{mg} / \mathrm{ml}$ IgG4. 
TABLE II

RECOVERY EXPERIMENTS: CONCENTRATIONS DETERMINED AFTER ADDITION OF KNOWN AMOUNTS OF MONOCLONAL IgG4 TO TWO NORMAL SERA

\begin{tabular}{llllc}
\hline $\begin{array}{l}\text { Original serum } \\
\text { concentration }(\mathrm{mg} / \mathrm{ml})\end{array}$ & $\begin{array}{l}\text { Added } \\
\text { quantity }(\mathrm{mg} / \mathrm{ml})\end{array}$ & \multicolumn{2}{l}{ Concentration $(\mathrm{mg} / \mathrm{ml})$} & \% Recovery \\
\cline { 3 - 5 } & 0.15 & 0.40 & 0.39 & \\
\hline 0.25 & 0.30 & 0.55 & 0.55 & 100 \\
& 0.60 & 0.85 & 0.94 & 110.6 \\
0.04 & 0.15 & 0.19 & 0.205 & 107.9 \\
& 0.30 & 0.34 & 0.35 & 102.9 \\
& 0.60 & 0.64 & 0.58 & 90.6 \\
\hline
\end{tabular}

It is worth noting that in our whole series, 4 sera were obviously lipidic and this completely prevented the binding of the antibodies to the coated plates. Serum samples should, therefore, be collected from strictly fasting subjects.

Recovery experiments were performed to make sure that other serum components did not interfere in the assay. As shown in Table II, observed and expected figures were in good agreement.

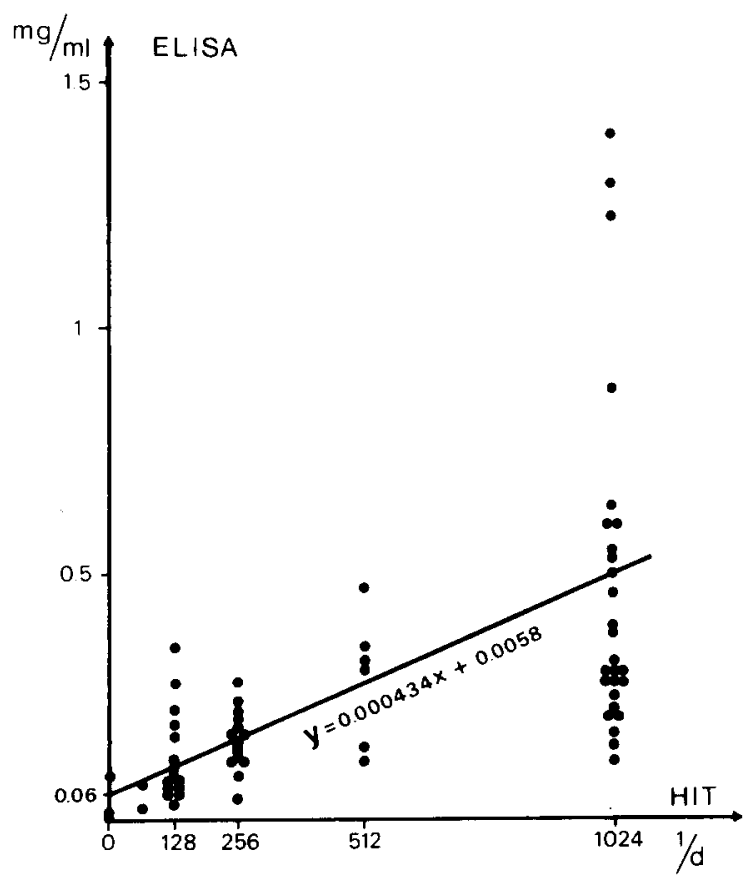

Fig. 3. Comparison between IgG4 titers obtained by HIT and expressed as limit dilutions (d), and values by competitive ELISA for the same sera. 
Within-run and between-run coefficients of variation $(\mathrm{CV})$ were evaluated with the same serum (mean concentration of $\mathrm{IgG} 4,0.27 \mathrm{mg} / \mathrm{ml}$ ) in 9 and 30 assays respectively. The intra-assay $\mathrm{CV}$ was $15 \%$ and the inter-assay $\mathrm{CV}$ was $17 \%$ in these experiments. Reproducibility clearly improved with practical experience of the technique since the $\mathrm{CV}$ found for the 10 last measurements decreased to $9 \%$.

Sixty-six sera (from 49 patients with malignant melanoma and 3 patients with atopy) were independently measured using ELISA and HIT. Results correlated $(P<0.001)$, but with a rather poor correlation coefficient as calculated by linear regression analysis ( $r=0.62$ ) (Fig. 3). This is not surprising since one of the two methods (HIT) is only semi-quantitative. When 41 sera from 35 allergic patients were tested by both ELISA and RID, correlation was found again $(P<0.001$, Fig. 4) and was slightly better than between ELISA and HIT (correlation coefficient $r=0.684$ ). Quantification of concentrations below $0.1 \mathrm{mg} / \mathrm{ml}$ was possible by ELISA and not by RID and the range of concentrations found in these 41 sera was greater by ELISA $(<0.01-1.55 \mathrm{mg} / \mathrm{ml})$ than by RID $(<0.1-0.8 \mathrm{mg} / \mathrm{ml})$.

IgG4 levels were determined by ELISA in sera from 173 blood donors aged 22-59 years (98 men and 75 women). Mean values and standard deviations were 0.300 and $0.417 \mathrm{mg} / \mathrm{ml}$ respectively in women and $0.465 \pm 0.371 \mathrm{mg} / \mathrm{ml}$ in men. This difference was significant ( $P<0.01$, Student's $t$-test). The 2 sexes also differed in the distribution of IgG4 levels (Fig. 5). It is noteworthy that nearly $10 \%$ of the women had no detectable serum IgG4 versus $1 \%$ of the men. The range was wide and similar $(<0.01-2.1 \mathrm{mg} / \mathrm{ml}$ in women and $<0.01-1.87 \mathrm{mg} / \mathrm{ml}$ in $\mathrm{men})$.

We also calculated mean IgG4 levels in different age groups (Table III). A tendency to increase with age was seen, though without statistical significance. When

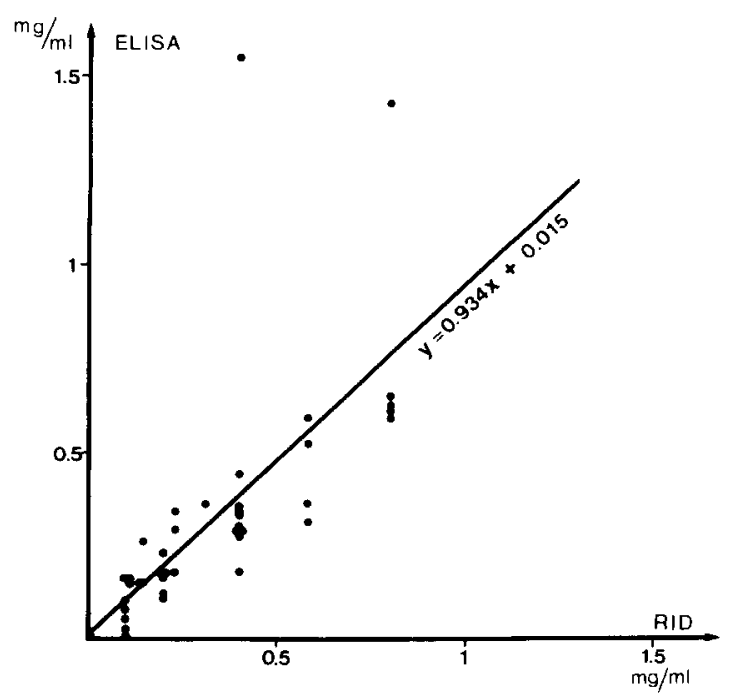

Fig. 4. Comparison of IgG4 levels obtained by RID and competitive ELISA for the same sera. 
TABLE III

SERUM IgG4 LEVELS AT DIFFERENT AGES

\begin{tabular}{llll}
\hline $\begin{array}{l}\text { Age } \\
(\mathrm{y})\end{array}$ & $\begin{array}{l}\text { Number of } \\
\text { sera }\end{array}$ & $\begin{array}{l}\text { Mean } \\
(\mathrm{mg} / \mathrm{ml})\end{array}$ & $\begin{array}{l}\text { Standard } \\
\text { deviation }(\mathrm{mg} / \mathrm{ml})\end{array}$ \\
\hline $22-29$ & 38 & 0.358 & 0.280 \\
$30-39$ & 54 & 0.343 & 0.337 \\
$40-49$ & 52 & 0.413 & 0.424 \\
$50-59$ & 29 & 0.505 & 0.549 \\
\hline
\end{tabular}

we compared the distribution of IgG4 levels in normal subjects and allergic patients (20 men and 13 women) no difference was detected.

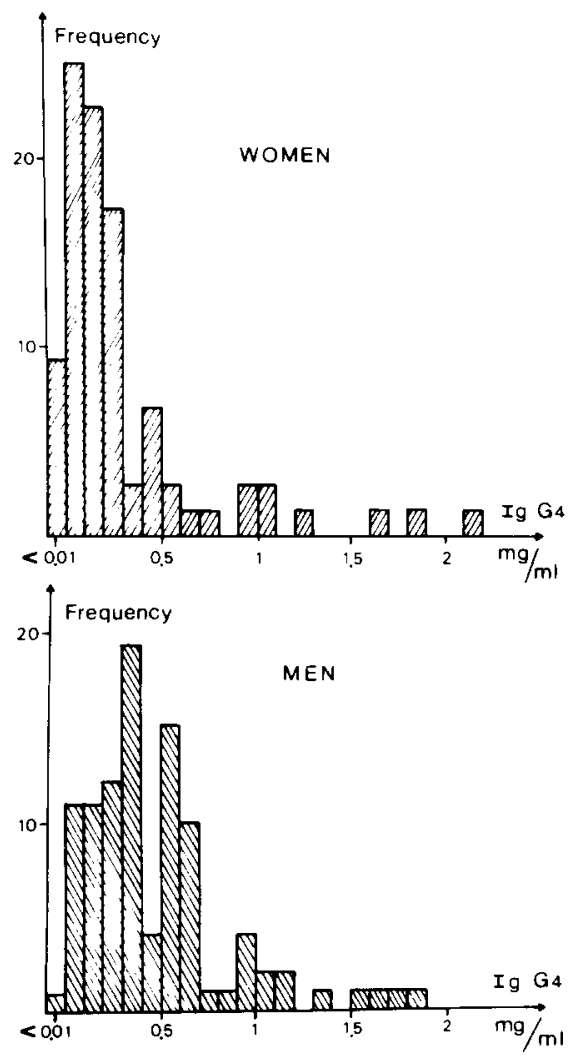

Fig. 5. Distribution of IgG4 levels in 173 normal adults ( 98 men and 75 women). 


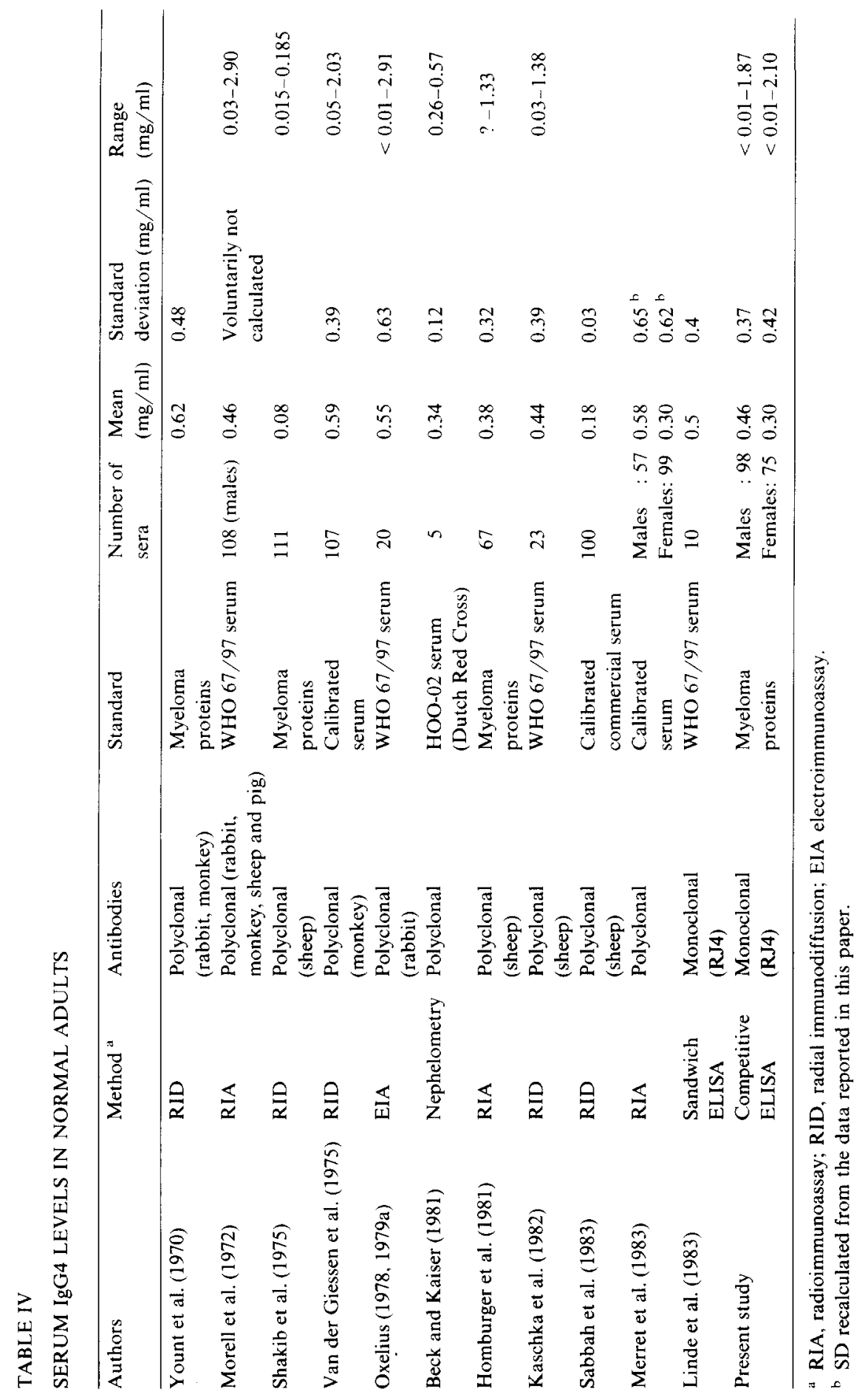




\section{Discussion}

The present report describes an immunoenzyme method for measurement of serum levels of IgG4. This indirect competitive ELISA used a monoclonal antibody and purified IgG4 myeloma proteins as standards. This is a difference from most published studies (Table IV) where calibrated sera were taken as reference. We felt that the availability of a highly purified standard, easy to calibrate and store, is an advantage, allowing inclusion of a complete calibration curve in each ELISA plate. The validity of such curves was supported by dilution and recovery experiments which clearly showed that the determinant recognized by the Mab was expressed by monoclonal as well as polyclonal IgG4.

As shown on Table IV, our results in 173 normal adults are in good agreement with previous studies. The striking difference of IgG4 serum levels in men and women which we found confirms the previous work of Merret et al. (1983). In our series, IgG4 was detectable in the serum of all but one man, whereas it was not found in nearly $10 \%$ of normal women, in accordance with the findings of Oxelius (1978 and 1979b). We are at present applying the method described above to other subclasses. Preliminary results of the measurement of serum IgG1 have not shown any difference according to sex.

The moderate increase of IgG4 levels with age probably relates to the well known increase in total IgG. We have so far little data on levels in childhood. Previous studies have found low levels, adult levels being reached much later (at about 12 years of age) for IgG2 and IgG4 than for IgG1 and IgG3 (Van der Giessen et al., 1975; Oxelius, 1979a, b; Zegers et al., 1980).

Results of our measurements of IgG4 levels in more than 300 sera make it clear that the competitive ELISA herein described is sufficiently accurate, reproducible and sensitive. The use of microtitration plates allows repeated measurement of large numbers of samples. Moreover, automation is easily feasible with a microcomputer to treat the data from the ELISA reader and obtain concentrations directly.

\section{Acknowledgements}

We are indebted to Drs. I.C.M. MacLennan, J.D. Capra, M.D. Cooper and C.B. Reimer for generous gifts of monoclonal antibodies, to Dr. F. Skvaril for his help in this study and for the kind gift of polyclonal anti-subclass sera, to Drs. L. Intrator and J. Gombert for the myeloma sera, and to Dr. D. Alcalay for collecting the normal serum panel.

\section{References}

Avrameas, S. and T. Ternynck, 1971, Immunochem. 8, 1175.

Beck, O.E. and P.E. Kaiser, 1981, Clin. Chem. 27, 310.

Daveau, M., J. Pavie-Fischer, L. Rivat, C. Rivat, C. Ropartz, H.H. Peter, J.-P. Cesarini and F.M. Kourilsky, 1977, J. Natl. Cancer. Inst. 58, 189. 
Homburger, H.A., G.L. Jacob and C. Bahler, 1981, Clin. Chem. 27, 1083, abstr. 297.

Kaschka, W.P., R. Hilgers and F. Skvaril, 1982, Clin. Exp. Immunol. 49, 149.

Lefranc, G.H. Chaabani, E. Van Loghem, M.-P. Lefranc, G. de Lange and A.-N. Helal, 1983, Eur. J. Immunol. 13, 240.

Linde, G.A., L. Hammarstrom, M.A.A. Persson, C.I.E. Smith, V.-A. Sundquist and B. Wahren, 1983, Infect. Immun. 42, 237.

Lowe, J., P. Bird, R. Jefferis and N.R. Ling, 1982, Immunology 47, 329.

March, S.C., I. Parikh and P. Cuatrecasas, 1974, Anal. Biochem. 60, 149.

Merret, J., M.L. Burr and T.G. Merret, 1983, Clin. Allergy 13, 397.

Morell, A., F. Skvaril, A.G. Steinberg, E. Van Loghem and W.P. Terry, 1972, J. Immunol. 108, 195.

Morell, A., F. Skvaril, J. Radl, L.J. Dooren and S. Barandun, 1975, in: Immunodeficiency in Man and Animals, eds. D. Bergsma, R.A. Good and N.W. Paul, Birth Defects, Original Article Series, 11 (The National Foundation-March of Dimes, Sunderland, MA) p. 108.

Natvig, J.B. and H.G. Kunkel, 1973, in: Advances in Immunology, 16 (Academic Press, London) p. 1.

Natvig, J.B., M. Harboe, O. Fausa and A. Tveit, 1971, Clin. Exp. Immunol. 8, 229.

Oxelius, V.-A., 1974, Clin. Exp. Immunol. 17, 19.

Oxelius, V.-A., 1978, Acta Path. Microbiol. Scand. 86 C, 105.

Oxelius, V.-A., 1979a, Acta Paediatr. Scand. 68, 23.

Oxelius, V.-A., 1979b, Clin. Exp. Immunol. 36, 112.

Oxelius, V.-A., A.B. Laurell, B. Linquist, H. Golebiowaska, U. Axelson, J. Bjorkander and L.A. Hanson, 1981, N. Engl. J. Med. 304, 1476.

Oxelius, V.-A., A.I. Berkel and L.A. Hanson. 1982, N. Engl. J. Med. 306, 515.

Parish, W.E., 1981, Brit. J. Dermat. 105, 223.

Pratt, J.J. and M.G. Woldring, 1976, Clin. Chim. Acta 68, 87.

Rivat, L., C. Ropartz, P. Burtin and D. Karitzky, 1969, Vox Sang. 17, 5.

Rivat, L., M. Daveau and C. Ropartz, 1974, Humangenetik 24, 173.

Rivat-Peran, L., D. Buriot, J.-P. Salier, C. Rivat, S.-M. Dumitresco and C. Griscelli, 1981, Clin. Immunol. Immunopath. 20, 99.

Sabbah, A., J. Le Sellin, M. Drouet and G. Heulin, 1983, Ouest Med. 36, 455.

Schur, P.H., H. Boret, E.W. Gelfand, C.A. Alper and F.S. Rosen, 1970, N. Eng. J. Med. 283, 631.

Shakib, F., D.R. Stanworth, R. Drew and D. Catty, 1975, J. Immunol. Methods 8, 17.

Terry, W.D., 1968, in: Immunologic Deficiency Diseases in Man, ed. D. Bergsma, Birth Defects, Original Article Series, 4 (The National Foundation - March of Dimes, White Plains, NY) p. 357.

Ugazio, A.G., T.A. Out, A. Plebani, M. Duse, V. Monafo, L. Nespoli and G.R. Burgio, 1983, in: Primary Immunodeficiency Diseases, eds. R.J. Wedgwood, F.S. Rosen and N.W. Paul, Birth Defects, Original Article Series, 19 (A.R. Liss, New York) p. 169.

Van der Giessen, M., E. Rossouw, T. Algra-Van Veen, E. van Loghem, B.J.M. Zegers and P.C. Sander, 1975, Clin. Exp. Immunol. 21, 501.

Van Nieuwkoop, J.A., A. Brand, J. Radl and F. Skvaril, 1982, Int. Arch. Allergy Appl. Immun. 67. 61. Walker, L., G.D. Johnson and I.C.M. MacLennan, 1983, Immunology 50, 269.

Yount, W.J., 1975, in: Immunodeficiency in Man and Animals, eds. D. Bergsma, R.A. Good and N.W. Paul, Birth Defects, Original Article Series, 11 (The National Foundation - March of Dimes, Sunderland, MA) p. 99.

Yount, W.J., R. Hong, M. Seligmann, R.A. Good and H.G. Kunkel, 1970, J. Clin. Invest. 49, 1957.

Zegers, B.J.M., M. Van der Giessen, E.E. Reerink-Brongers and J.W. Stoop, 1980, Clin. Chim. Acta 101, 265. 